\title{
Comparison of Film Language and Historical Fact
}

\author{
Katherine Kowalewski
}

In the study and analysis of historical films, the evidence will reveal that these films have many dissimilar genres. For example: 12 Years a Slave, Nanking, and Frida are movies that come from three disparate film genres but through the analysis of these films in their relation to historical events, these films can also be classified as historical documents that recreate significant events for historical purpose. The drama 12 Years a Slave, the documentary Nanking, and the biopic Frida can also be analyzed and compared in terms of the use of film language. The language of the film incorporates metaphors and symbols, the characters' actions, dialogue, and most notably, film cinematography.

12 Years a Slave is a dramatic historical film directed by Steve McQueen based on the autobiography written by Solomon Northup reflecting on his time spent in the Southern United States as an African-American slave. ${ }^{1}$ Although this film can be viewed as a biopic of Solomon Northup's personal experiences in life, it also reflects on the general brutality that was far too common for the black slaves in the antebellum south. The film begins in 1841 with a brief scene of Northup's life in New York state as a free black man. On a trip to Washington D.C., Northup is kidnapped and sold as a slave and transported to the southern state of Louisiana with no legal documents to prove his status as a free African-American. The film shows the struggles and hardships that Northup, who was given the slave name of Platt, faced working on southern plantations. The film chronicles several decades and expresses an overall theme of slavery and injustice that was an integral part of the southern states. Director McQueen successfully brings awareness to the inequality that AfricanAmericans faced during that time.

Nanking is a historical documentary directed by Bill Guttentag and Dan Sturman telling the story of the Nanking massacre, which took place during World War II, and the Caucasian foreigners who saved many Chinese citizens during the bombing. ${ }^{2}$ The documentary captures the horror of the mass murder through actual footage from the bombings, interviews with survivors, and reenacting fictional narrative interviews with the westerners who risked their lives to save as many people as they could. In December of 1937, the Japanese army invaded China, killing over 200,000 people in the former capital city Nanking. Several white people living in the city were able to construct a refuge for Chinese citizens that was promised to be bomb-free. They were able to save 250,000 Chinese citizens. A common theme depicted in the documentary is remembrance, appreciation, and courage. Hollywood actors play the role of the brave westerners in an interview format that gives the documentary an authentic feel despite our being unable to hear actual testimonies from the heroes.

Frida is a historical biopic film directed by Julie Taymor that follows the life of the renowned Mexican artist Frida Kahlo. ${ }^{3}$ The film gives the audience an insight into Kahlo's

${ }^{1} 12$ Years a Slave, directed by Steve McQueen, (2013).

${ }^{2}$ Nanking, directed by Bill Guttentag and Dan Sturman, (2007).

${ }^{3}$ Frida, directed by Julie Taymor, (2002). 
life as an artist, a lover, and a person suffering from a immobilizing disability. The film begins with the tragic bus accident that left her bedridden and immobile which then progresses on to show the challenges she faced with her unfaithful husband, Diego Rivera, as well as the affair she had with Leon Trotsky. The majority of the film takes place during the height of Kahlo's career depicting her as a modern woman of Mexico. The common theme of this biopic is feminism and pride, both traits depicted by Kahlo's character. What is truly remarkable is how ahead of her time Kahlo was and how the film is able to communicate her contemporary style in not only her art, but in her lifestyle.

The three aspects of film language depicted in each of the three films are the metaphors hidden in character's actions, dialogue, and use of cinematography. Closely analyzing characters' movements in film reveals great details to the storyline that aids the audience in receiving a deeper understanding of the film they are watching. Dialogue in historical film, although often made up from a script, provides historical accuracy in the language and tone used by the characters. Lastly, the director's use of cinematography communicates to the audience unspoken emotion from characters and overall theme of the film.

12 Years a Slave is a film full of symbolism through the use of the film language previously mentioned. Metaphors depicted by the character's actions are noticed throughout the entire movie. Near the beginning of the film, when Solomon Northup has been drugged by his "comrades" the men take him to bed and blow out the candles in his room. ${ }^{4}$ The action of blowing out the candles symbolizes the light leaving Northup's life and the transition to a dark part of his life. Where he had once experienced joy, freedom, and equality he is now moved into a shadowed point of his existence. Further into the film, a slave girl named Patsey is seen making dolls out of corn husks. ${ }^{5}$ Jim Downs, a historian and author, speaks of the symbolism of this action in a film roundtable interview, "this reveals first that her pleasure and enjoyment still require her physical labor and the ingredients of plantation slavery. It then shows her desire for solitude, to not be bothered by anyone; she intently fashions the husks into figures, but she does not look around or talk to anyone nearby." ${ }^{\prime \prime}$ As suggested by Downs, the action of Patsey making the dolls symbolizes how obnoxious the enslavement impacted all aspects of the slave's lives and how even during her "time off" Patsey was surrounded by her work and used it in her leisure as well. Using dialogue in film is the most obvious form of analyzing feeling and meaning. When Northup is on a boat travelling to Louisiana to be sold as a slave, he is told to do and say as little as possible in order to survive. Northup is completely unsatisfied with the idea of living his life in that way and he retaliates by saying "I don't wanna survive - I wanna live." This statement precisely communicates Northup's strong will to live and go back to his life as a free black man. This one sentence uttered in the quiet hold of a rocking boat translates to great willpower and emotion from the main character. Similarly, when first captured, Northup wakes up in shackles and states his freedom to the men holding him captive. The white man responds to him by saying: "You no free man. And you ain't from Saratoga. You

\footnotetext{
${ }^{4} 12$ Years a Slave, (2013).

${ }^{5}$ Ibid.

612 Years a Slave, Civil War History 60, no. 3 (Kent State University Press, 2014), 324.

${ }^{7} 12$ Years a Slave, (2013).
} 
from Georgia. You ain't a free man. You nothin' but a Georgia runaway. You a runaway nigger from Georgia." ${ }^{\prime}$ The repetition in his sentences drills the idea into Northup's mind, with the aim of brainwashing Northup into believing what is being said. This foreshadows the loss of identity Northup will begin to face as a slave for the next several years. However, despite the attempt at brainwashing, the strength and sense of self that Northup/Platt manages to display is evident throughout the entire film. The cinematography of the movie communicates an ample amount of feeling and often foreshadows what is ahead in the movie. Natalie Zemon Davies from the University of Toronto analyzes the lengthy close-ups on the characters' faces to convey their feelings in a direct but silent way. ${ }^{9}$ Davies notes the irony in the cinematography of the contrasting images of the scenic plantation versus the violent reality of slave life. ${ }^{10}$

"Like the work of written history, the documentary 'constitutes' facts by selecting traces of the past and enfolding them into a narrative."11 This is true in the historical documentary Nanking. The documentary uses Hollywood actors to portray the roles of individuals who were present during the atrocities of Nanking. The presentation of attitudes varies between the Chinese survivors interviewed and the white actors playing the role of the heroes. Chang Zhi Qiang, who was age 9 during the time of the attacks, consistently avoids eye contact with the camera whereas the white men and woman steadily look straight on. The Chinese man avoiding the camera is expressing his sorrow and reverence towards the tragedy. However, the directness depicted by the westerners radiates their confidence and pride, which they rightfully claim after saving thousands of Chinese citizens. One of those westerners John Rabe even received the nickname the "Oskar Schindler of China."12 The most compelling dialogue comes from two of the Japanese soldiers that survived the war. Daimon Yoshio begins by saying: "The military order was that now we had to mop up the city of Nanking," followed by Japanese corporal Deguchi Gonjiro recalling the outcome of the bombs, "by the time we reached the outskirts of the city, the dead covered the ground like a straw mat."13 These direct quotes taken from men who participated in the massacre convey the remorseful attitude they had when ordered to mop up the city of Nanking. To the Japanese military, the city was nothing but a dirty floor. Both the survivors compared the city to something they would walk on - something to mop and a straw mat. This indicates the superiority the Japanese army felt over the Chinese citizens. Symbolism in cinematography is evident when the Japanese soldiers recall the mass murders they had committed. The camera zooms in on their faces to further personalize the horrendous acts they had been ordered to commit. This emphasizes the

${ }^{8} 12$ Years a Slave, (2013).

${ }^{9} 12$ Years a Slave, Civil War History, 312.

${ }^{10}$ Ibid.

${ }^{11}$ Robert A. Rosenstone, History on Film/Film on History, 2nd ed. (Harlow: Pearson Education Limited, 2012), 79.

${ }^{12}$ Quinna Shen, "Revisiting the Wound of a Nation: The 'Good Nazi' John Rabe and the Nanking Massacre," Seminar 47, no. 5 (2011): 661.

${ }^{13}$ Nanking, (2007). 
Kowalewski, "Comparison of Film Language" 154

reality of the crimes they had committed, showing the audience the actuality of the situation. ${ }^{14}$

The biopic, Frida, depicts the life of a female Mexican artist who made art that was beyond its years and lived her life as a modern-day feminist. The film successfully communicates actions that develop Kahlo's character and themes throughout the entire film. When Diego Rivera takes the quirky Frida Kahlo on a date to a friend's party she outdrinks the men and takes it upon herself to dance with the beautiful hostess. The two dance a provocative sexual tango that turns the heads of everyone in the room. This action initiated by Kahlo is the first insight given to the audience of her bisexuality. Journalist Jean Roberta writes of Kahlo's sexual preferences as being "a bisexual before it was hip." ${ }^{15}$ Her upfront attitude that is blatantly displayed during this dance is a metaphor for the guards she puts up throughout her entire marriage and her unrestrained response to the people watching her dance expresses an outlet for her feelings of betrayal. When her husband continuously cheats on her, she retaliates by having affairs with women as a way of responding to the betrayal. The dialogue used in the film also sets the theme of Kahlo's stubborn lifestyle. When asking her future husband for an honest opinion on her artwork, Diego Rivera surprises her with an unsuspecting statement, "what do you care about my opinion? If you're a real painter you'll paint because you can't live without painting. You'll paint 'til you die."16 Kahlo takes this statement very seriously. This frames the entire theme of the movie with Frida Kahlo's overwhelming desire to paint. After every hardship faced, Kahlo paints a picture to represent it. Her artwork conveys her feelings and sufferings. As Rivera had said, she did paint until she died - which is seen at the end of the film when Frida is on her deathbed, still making art. ${ }^{17}$ Furthermore, the cinematography of the film aids the audience in comprehending Diego Rivera's disrespectful behaviour towards his wife with his unfaithful tendencies. At the end of the movie, Rivera returns to Kahlo after her toes had been amputated and once again asks to renew their marriage. During the scene, Rivera's face is half shadowed and half turned into the light. ${ }^{18}$ This is a representation of Rivera finally grasping the vows of his marriage and coming out of the philandering life he had been leading until then.

There are similarities in film language throughout all three films. The cinematography in each film successfully communicates the character's' feelings. The common camera technique used to do this is the close-up on the characters' faces. Camera close-ups provide the audience a clear view of which emotions are being transmitted from the actors' eyes, which gives each film deeper meaning. Furthermore, dialogue in the three films also conveys much about the characteristics of the people portrayed in the film. In each movie analyzed, the dialogue was able to convey how deeply words can affect the way a character is developed.

\footnotetext{
${ }^{14}$ Nanking, (2007).

${ }^{15}$ Jean Roberta, “Frida's Wounded Body and Soul," Gay and Lesbian Review Worldwide, November/December, 2014.

${ }^{16}$ Frida, (2002).

${ }^{17}$ Ibid.

${ }^{18}$ Ibid.
} 
The differences in film language effects between each movie are most obvious in the actions. In 12 Years a Slave the movements and actions of the characters often foreshadow what is to come. In Frida her quirky actions provide the audience an introspective insight into her true personality, which in the film language of a biopic, we absorb and then emphasize with Frida's trials and tribulations of her painful life. Additionally, in the documentary Nanking, the actions portray the people's personality traits depicting the humble Chinese and Japanese men as well as the proud westerners. Although all three films triumphantly use a character's action to communicate meaning and metaphors to the audience, each one uses it to convey a different message to the viewers.

In conclusion, when analyzing film language of movies a greater understanding is developed of the characters, symbols, and settings. Consequently, a significant appreciation is developed for film and the historical messages they convey. Indeed, after an analysis of the action, dialogue, and cinematography of the three movies - 12 Years a Slave, Nanking, and Frida a better understanding of the history in the respective time periods is apparent and it can be concluded from the evidence presented that the films analyzed can be considered historical documents. 


\section{Bibliography}

"12 Years a Slave." Civil War History 60, no. 3 (Kent State University Press, 2014), 310-36.

12 Years a Slave. Directed by Steve McQueen. 2013.

Frida. Directed by Julie Taymor. 2002.

Nanking. Directed by Bill Guttentag and Dan Sturman. 2007.

Roberta, Jean. "Frida's Wounded Body and Soul." Gay and Lesbian Review Worldwide, November/December, 2014.

Rosenstone, Robert A. History on Film/Film on History. 2nd ed. Harlow: Pearson Education Limited, 2012.

Shen, Quinna. "Revisiting the Wound of a Nation: The 'Good Nazi' John Rabe and the Nanking Massacre." Seminar 47, no. 5 (2011): 661-78. 